\title{
HAZAI NAGYVÁLLALATI ETIKAI KÓDEXEK TARTALMI ELEMZÉSE
}

Az etikai kódexek az etikai értékek, normák, alapelvek, magatartási szabályok írásba foglalását jelentik, és hozzájárulnak annak tisztázásához, hogy a vállalatok üzleti hétköznapjaiban mit tekintenek legitimnek és felelôsségteljesnek. A cikk az etikai kódexek szerepének szakirodalmi áttekintése után az 50 legnagyobb árbevételú hazai cég közül azok etikai kódexét vizsgálja, amelyek magyar nyelvú etikai kódexe az interneten elérhetố. A tartalmi összehasonlítás kiterjed a magyar és az amerikai gyakorlatra is. Az elemzés gondolatébresztốként szolgálhat az etika intézményesítését tervezố vállalatok számára. ${ }^{1}$

Kulcsszavak: üzleti etika, vállalati etika, etikai intézményesítés, etikai kódex

Az üzleti etika, és ezen belül a vállalati etika, egyik sarkalatos pontja, hogy a vállalati környezet változásai olyan folyamatokat indítottak el, amelynek eredményeként a ,jó vállalat” manapság már nemcsak az üzleti szempontból sikeres vállalatot jelenti, hanem a hiteles és etikus vállalatot, amely arra törekszik, hogy megfeleljen a társadalmi elvárásoknak, optimalizálva a vállalat érintettekre gyakorolt hatását, és minimalizálva tevékenysége káros hatásait (Epstein, 2006).

A szervezeten belüli etikus magatartásra egyrészt az egyéni jellemzók, valamint a szervezeti tényezók vannak jelentôs hatással (Hassink - de Vries - Bollen, 2007). A szervezetek az etikus viselkedést vagy munkavállalóik morális szúrésével, vagy olyan környezet megteremtésével tehetik lehetôvé, ami csökkenti az etikátlan magatartás valószínúségét (Trevino, 1986). A morális környezet fejlesztésének, és egyben az etika vállalati intézményesítésének legismertebb eszközei az etikai kódexek, amelyek egyes szerzók szerint manapság nyilvánvaló sajátosságai a modern üzleti szervezeteknek (Cowton - Thompson, 2000). Az etikai kódex a szervezeten belüli és kívüli gyakorlatot és kapcsolatokat irányító vállalati alapelvek és szabályok formalizált, nyilvános kinyilatkoztatását jelenti. Az etikai kódex mind a jelenlegi, mind a jövốbeli magatartás vezérfonala, meghatározza a vállalati alkalmazottak etikai értékeit és felelősségeit egymás és más szervezeti stakeholderek iránt (Kaptein - Schwartz, 2008). Sajátossága, hogy önszabályozásra szolgál (Schwartz,
2001). Kevésbé az írásbeli eredmény, mint maga a létrehozás folyamata jelenti az etikai kódex igazi kihívását (Newton, 1995; Ulrich - Lunau - Weber, 1996).

\section{A vállalati etikai kódexek szerepe}

Kaptein és Schwartz (2008) az etikai kódexek hatékonyságával foglalkozó munkájukban összefoglalták a vállalati etikai kódexek szerepéról és hatásáról megfogalmazott, sokszor egymással is ütköző véleményeket. Egyes kutatók szerint a vállalatoknak önzetlenül kell etikai kódexszel rendelkezniük, csupán azért, mert ez a helyes cselekedet (L'Etang, 1992), vagy azért, mert ez annak a módja, hogy kinyilvánítsák és menedzseljék morális felelősségüket, hozzájárulva a társadalmi problémák megoldásához (Logsdon - Wood, 2005).

\section{Érvek az etikai kódex mellett}

A korai empirikus felmérések során megkérdezett menedzserek jelentôs része úgy ítélte meg, hogy a vállalati etikai kódexek pozitívan hatnak a vezetôi döntési gyakorlatra és a vállalati magatartásra, de hogy mekkora ez a hatás, abban már eltértek a vélemények (Becker - Frietzsche, 1987). Singhapakdi és Vitel (1990) marketingterületen dolgozókat vizsgáltak, és megállapították, hogy azok, akiknek etikai kódexben leírt szabályokat kell betartaniuk, sokkal érzékenyebbek az etikai problémák iránt, és döntésükkor gyakran az etikus megoldást választják. Az etikai kódexek megôrzik és 
javítják a vállalat hírnevét (Bowie, 1990), csökkentik a jogszabályok megszegése esetén kiszabott büntetést (Pitt - Groskaufmanis,1990), arra ösztönzik a hatóságokat, hogy enyhítsenek a szabályozáson és a kontrollon (Clark, 1980), növelik a szervezeti hatékonyságot (Mezher - Jamali - Zreik, 2002) és javítják a szervezeti munkaklímát (Manley, 1991). Az etikai kódexek leveszik a felelősséget az egyszerú egyének válláról (Schwartz, 2000). A kódexektôl az alkalmazottak gyakran érzik jobban és nagyobb biztonságban magukat a cégükön belül, míg a vevốknek és az érintetteknek nagyobb bizalma van a cég iránt (Wood, 2000). Akik pozitívan ítélik meg, azok szerint az etikai kódexek szükségesek (Rezaee - Elmore - Szendi, 2001), fontosak (Cooper, 1990), értékesek (Wood - Rimmer, 2003), létfontosságúak (Coughlan, 2005), felbecsülhetetlenek (Sethi, 2002) és sikeresek (Dobson, 2005).

\section{Érvek az etikai kódex ellen}

Vannak azonban olyan kutatók is, akik nagyon kritikusak a vállalati etikai kódexek értékeivel szemben. Matthews (1990) szerint a vállalati felelős magatartás és a kódexek megléte között nem mutatható ki szignifikáns kapcsolat, a cég érdekének védelmére íródnak az alkalmazottakkal szemben. Sok esetben a vállalatvezetés értékrendjének másokra eróltetését jelentik, és inkább az erkölcstelen, mintsem az erkölcsös cselekedetekre ösztönöznek. Az általuk nem érintett területen „szabad a vásár”. A vállalat számára profitvesztéssel járó magatartást tiltják (például sikkasztás), míg a nyereséggel vagy megtakarítással járó cselekedetek (például környezetszennyezés, biztonsági normák megszegése) nem kerülnek be a kódexbe (Cressey - Moore, 1983). Az üzleti kódexek gyengítik az alkalmazottak felelősségét, valamint megalázóak, fenyegetőek és vádlók (Raiborn - Payne, 1990). A részvényeseket gyanakvóbbá, cinikussá és hitetlenné teszik (Dobel, 1993), többe kerülnek, mint amennyit érnek (Hess - McWhorter - Fort, 2006) és kevésbé hatékonyak, mint az ágazati kódexek vagy a törvények (McClintock, 1999).

\section{Az etikai kódexek gyakorlati szerepe}

A vállalati etikai kódexek gyakorlati szerepére vonatkozóan Schwartz (2001) metafóráit kiegészítve a következő fő típusokat különböztethetjük meg (Szegedi, 2011):

1. „Kirakatdísz” - A kritikusok szerint sokszor csak kirakatdísznek készül az etikai kódex (White Montgomery, 1980; Weaver - Trevino - Cochran, 1999), nincs valódi szerepe, egyedül az a fontos, hogy legyen ez is a vállalatnak. Az ilyen kódexek felületes és zavaró válaszokat adnak az etikus vállalati viselkedéssel kapcsolatos kérdésekre (Warren,
1993) és gyakorlati hatás nélküliek (Norberg, 2009), sốt árthatnak is, mivel a munkavállalók érzékelik a kirakat szerepét. Az Enron részletes etikai kódexét a botrány után cinikusan ,alig használt kódex”-ként árulták az interneten (Warner, 2001), a szakirodalom felhívta a figyelmet arra, hogy a kódex ,,cowboy" kultúrával társult, amiben a szabályokat rendszeresen megszegték, és az agresszív, individualista magatartást jutalmazták (Stevens, 2008).

2. „Szabálygyújjtemény” - Az etikai kódex tartalmazhat szabályokat, ebben az értelemben valóban szabálygyứjteményként értelmezhetjük. De a kódexek jelentős része értékeket is tartalmaz, sốt kimondottan értékorientált is lehet, ebben az esetben a szabálygyújitemény nem állja meg a helyét. A szabálygyújtemény kifejezést negatív értelemben is használják, ami arra utal, hogy a kódexszel a vállalat célja csak a dolgozók megregulázása.

3. „Tükör” - A tükör kifejezés arra utal, hogy az etikai kódex megerősíti az elfogadható viselkedést. Természetesen tartalmazhat olyan normát is, amely még nem része a vállalati kultúrának, de szeretné a vállalat, hogy az legyen. Az etikai kódex világos jelzés arra, hogy a vállalat tudatában van az etikus viselkedés szükségességének, és elvárja munkavállalóitól az etikus viselkedés melletti elkötelezettséget (O’Dwyer - Madden, 2006).

4. „Irányjelzó” - Az etikai kódex megmutatja, hogy mi a helyes és mi a helytelen viselkedés. A vállalatnál dolgozó egyének különböző kultúrákból, különböző közösségekból jönnek, ahonnan eltérô etikai normákat hozhatnak magukkal. A kódex irányjelzô számukra, hogy mi az elvárt viselkedés a vállalat múködése során. Világos elvárásokat fogalmaz meg (Schwartz, 2001). Útmutatóként szolgál a munkavállalók számára ahhoz, hogy kövessék a vállalati értékeket és normákat. (LRN, 2010).

5. „Pajzs” - Az etikai kódex szolgálhat pajzsként a vállalatok számára, hiszen megvédheti a céget a helytelen viselkedéstól, és ösztönözheti a helyes cselekedeteket (Cleek - Leonard, 1998). A jogszabályok több országban ösztönzik a vállalati etikai kódexek kialakítását, annak érdekében, hogy megelőzzék a jogszabálysértést.

6. „Segitség”-A kódex több értelemben is jelenthet segítséget. Egyrészt célja lehet a vállalati botrányok után megrendült bizalom helyreállítása, másrészt segíthet megórizni vagy javítani a vállalat hírnevét, megelőzni a közvélemény kritikáját (Bondy - Matten - Moon, 2004). Az etikai dilemma szituációkat az egyén stresszként élheti meg, így az etikai kódex segítheti az egyéni döntéseket. 
7. „Füstjelzó” - Értelmezhetjük az etikai kódexet füstjelzóként, ugyanis lehetôséget ad az etikátlanságok megelőzésére (Schwartz, 2001).

8. „Alap” - Az etikai kódexet sok szerzố az etikai program alapjának tekinti (Murphy, 1988), ugyanis az etikai normák írásba foglalása alapot teremt a többi etikai intézkedés bevezetésére.

9. „Elsó lépés” - Az etikai kódex az etikus vállalati kultúra kiépítésnek elsố lépése (Wood - Rimmer, 2003). Az etikai kódex megalkotása csak egy kezdő lépése egy etikai programnak, mivel az értékek és a helyes viselkedés tudatosítása nélkül nem garantálja az etikus viselkedést (Ross - Benson, 1995).

Kaptein és Schwartz (2008) az etikai kódexek hatékonyságával foglalkozó munkájukban csaknem 80 etikai kódexszel foglalkozó tanulmányt vizsgált meg. A tanulmányok $35 \%$-a pozitívan értékelte, azaz hatékonynak találta az etikai kódexeket, $16 \%$ szerint gyenge kapcsolat van, 33\% szerint nincs szignifikáns kapcsolat a kódexek léte és a vállalat etikussága között, $14 \%$ kevert eredményeket mutatott, és csak egy esetben mutatták ki, hogy a kódex ellenkezó hatást váltott ki, mint amit elérni szerettek volna vele. Kaptein és Wempe (1998: p. 853.) hangsúlyozza, hogy „,a kódex semmi, a kódex kialakítása minden". A rendszeres újraértékelés és korrigálás fontosságát több kutatás megállapítja, és hangsúlyozza, hogy a kódexnek élő dokumentummá kell válnia. Ezenkívül, az etikai kódexben megfogalmazott önkéntes kötelezettségvállalás csak abban az esetben lesz hatásos, ha a szándék kinyilvánítását konkrét tettek is követik.

\section{Hazai nagyvállalati etikai kódexek}

A jelen vizsgálat célja a hazai nagyvállalati etikai kódexek tartalmának az összehasonlítása. A mintába az 50 legnagyobb árbevételú hazai cég (HVG, 2011) közül azok kerültek be, amelyek az interneten elérhetô, magyar nyelvú etikai vonatkozású dokumentummal rendelkeztek. Az elemzés kiterjedt annak megállapítására, hogy milyen sajátosságai vannak a vizsgált kódexeknek, milyen hasonlóságok és különbségek fedezhetók fel az egyes vállalatok etikai kódexében. Nincs jó vagy rossz gyakorlat, hiszen az etikai kódex és más etikai intézmények milyensége és hatásossága függ az ágazattól, az adott vállalati kultúrától és más vállalati sajátosságoktól. A vizsgálat során 14 cég etikai dokumentuma került összehasonlításra, ezek a következók voltak: Mol Nyrt., Nokia Komárom Kft., E.ON Földgáz Trade Zrt., Magyar Telekom Nyrt., Tiszai Vegyi Kombinát Nyrt., TIGÁZ Tiszántúli Gázszolgáltató Zrt., Richter Gedeon Vegyészeti Gyár Nyrt., Shell Hungary Kereskedelmi
Zrt., OMV Hungária Ásványolaj Kft., Mol Energiakereskedő Zrt., Borsodchem Zrt., Metro Kereskedelmi Kft., Szerencsejáték Zrt., Telenor Magyarország Zrt.

A vizsgálati minta nem tekinthetô reprezentatívnak, a megállapítások csak adott körben érvényesek, nem általánosíthatóak a hazai vállalatok egészére. Az 1. táblázat a vizsgált vállalatok és kódexek fő jellemzôit tartalmazza. Az elemzés kizárólag a vizsgálat időpontjában a vállalati honlapokon található etikai dokumentumokon alapszik (Mol Group, 2012; Nokia, 2011; E.ON Földgáz Trade Zrt., 2012; Magyar Telekom Nyrt., 2011; TIGÁZ Tiszántúli Gázszolgáltató Zrt., 2008; Richter Gedeon Vegyészeti Gyár Nyrt., 2009; Shell, 2006; OMV, 2009; Mol Energiakereskedő Zrt., 2012; BorsodChem Csoport, 2008; Metro, 2012; Szerencsejáték Zrt., 2010; Telenor, 2010).

A vállalat etikai értékeit, illetve normáit tartalmazó kódexre többféle elnevezés jelenik meg a szakirodalomban és a vállalati gyakorlatban egyaránt. A vizsgált 14 vállalat döntő többségében (79\%) etikai kódex az etikai dokumentum neve, egy-egy esetben magatartási kódex (Nokia), múködési kódex (Magyar Telekom), illetve üzleti alapelvek (Metro). A továbbiakban az egyszerúség kedvéért az etikai kódex kifejezést használom. A kódexek terjedelme között jelentős különbség van. A legrövidebb 2 oldal (Mol Energiakereskedő Zrt.), a leghosszabb 80 oldal (Shell), az átlag 20 oldal. A vizsgált kódexek mintegy 60\%-a részletesen fejti ki az érintett témákat (MOL, EON Földgáz Trade, Magyar Telekom, TIGÁZ, Shell, OMV, Borsodchem, Szerencsejáték).

A részletezettség részben összefügg az orientációval, azaz hogy mennyire alapelv-orientált és mennyire szabályorientált a kódex. A világ nagyvállalatainak gyakorlata azt mutatja, hogy a vállalatok viszonylag kis része (13\%) alkalmaz tisztán szabályorientált kódexet, 35\%-uk alapelv-orientált kódexet használ, a kódexek többsége (52\%) viszont kevert, azaz mind alapelvek, mind szabályok megjelennek bennük (KPMG, 2008). Ez a tendencia még inkább érvényre jut a vizsgált kódexekben, ugyanis 70\%-uk tartalmaz alapelveket és szabályokat is, és mintegy 30\%-uk alapelv-orientált. A vegyes kódexek túlnyomó részében (77\%) azonban inkább a szabályorientáció dominál, és csak kisebb részük (23\%) inkább alapelv-orientált. A tapasztalatok szerint a szabály-, illetve az alapelv-orientáció különbségére utal a kódex szóhasználata is, ugyanis alapelvorientáció esetén gyakrabban találkozunk a „mi”, míg szabályorientáció esetén a „ön” kifejezéssel (KPMG, 2008). A vizsgált kódexek jórészt alátámasztják ezt a megállapítást. Az alapelv-orientált kódexek egyértelmúen többes szám elsố személyt használnak, míg az inkább szabályorientált kódexek általában beszélnek a 


\begin{tabular}{|c|c|c|c|c|c|c|c|}
\hline & $\dot{q}$ & 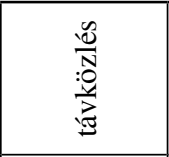 & 苛 & $\begin{array}{l}\frac{\pi}{0} \\
\frac{0}{0} \\
r\end{array}$ & 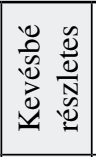 & 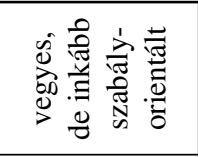 & 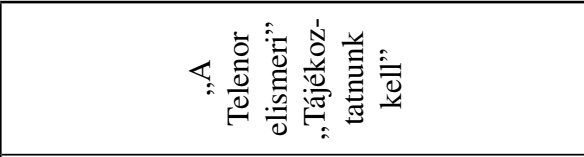 \\
\hline 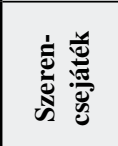 & $\ddot{f}$ & 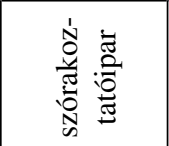 & 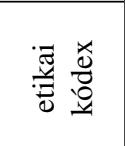 & $\begin{array}{l} \\
\frac{\pi}{0} \\
0 \\
n\end{array}$ & 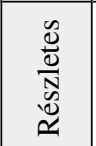 & 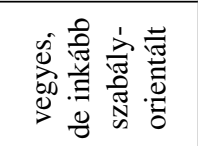 & 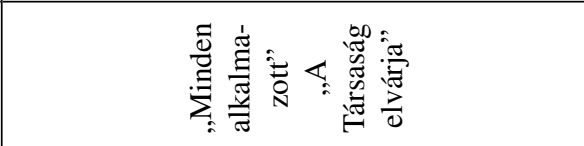 \\
\hline 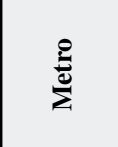 & $\dot{\forall}$ & 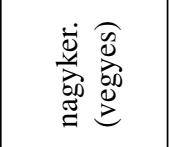 & $\begin{array}{l}\frac{y}{0} \\
: \frac{\bar{d}}{\frac{D}{0}} \\
\frac{\pi}{\pi}\end{array}$ & $\begin{array}{l}\frac{\pi}{0} \\
\frac{0}{0} \\
m\end{array}$ & 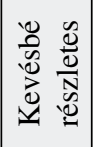 & $\begin{array}{l}\stackrel{0}{\Delta} \\
\stackrel{0}{>} \\
\stackrel{>}{0}\end{array}$ & 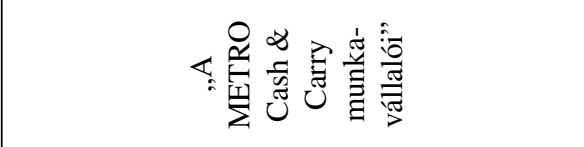 \\
\hline 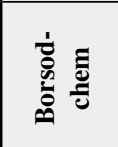 & $\dot{m}$ & 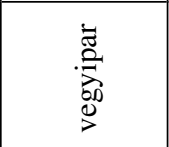 & 氶若 & \begin{tabular}{l|} 
\\
$\frac{\pi}{0}$ \\
0 \\
\end{tabular} & 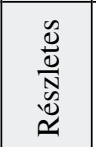 & 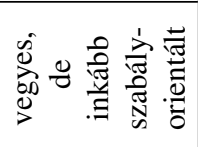 & 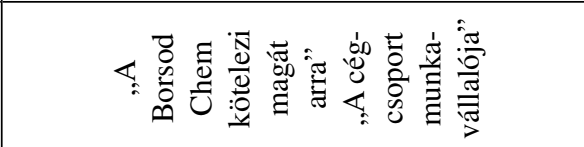 \\
\hline 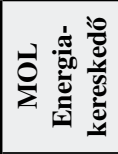 & $\dot{m}$ & 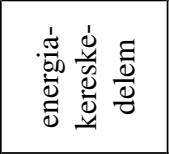 & 吾希 & $\begin{array}{l}\frac{\pi}{0} \\
\frac{\pi}{0} \\
\text { N }\end{array}$ & 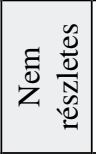 & 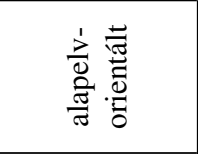 & 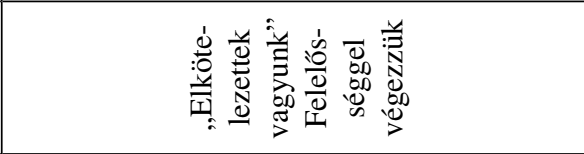 \\
\hline$\grave{z}$ & तें & 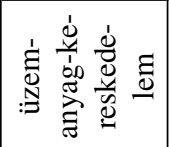 & 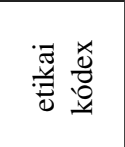 & \begin{tabular}{l|} 
\\
$\frac{\pi}{0}$ \\
0 \\
0 \\
0
\end{tabular} & 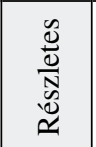 & 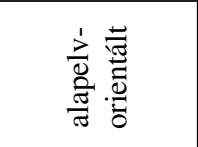 & 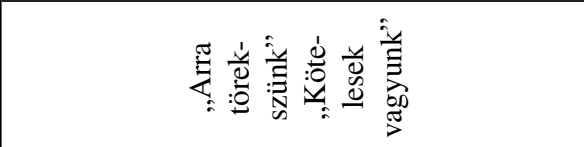 \\
\hline$\overline{\overline{\bar{E}}}$ & $\dot{\sim}$ & 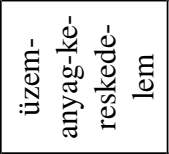 & 矛宏 & $\begin{array}{l}\bar{\pi} \\
\frac{\pi}{0} \\
\stackrel{\infty}{\infty}\end{array}$ & $\begin{array}{l}\frac{\mathscr{u}}{0} \\
\frac{0}{N} \\
\stackrel{0}{0} \\
\simeq\end{array}$ & 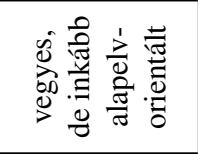 & 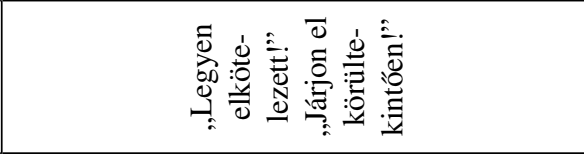 \\
\hline & $\dot{d}$ & 窝芯 & 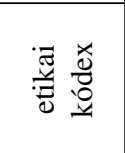 & $\begin{array}{l}\frac{\pi}{0} \\
\frac{0}{0} \\
=\end{array}$ & 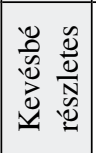 & 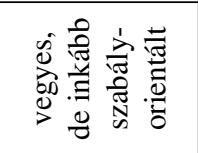 & 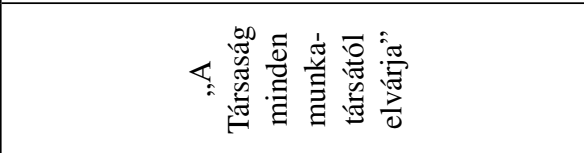 \\
\hline 赵 & ત่ & 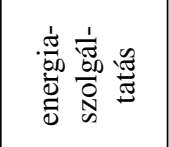 & 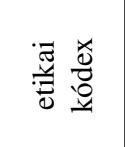 & \begin{tabular}{l|}
$\frac{\pi}{0}$ \\
$\stackrel{0}{0}$ \\
$\stackrel{+}{+}$
\end{tabular} & $\begin{array}{l}\mathscr{0} \\
\frac{0}{N} \\
\ddot{d} \\
\simeq\end{array}$ & 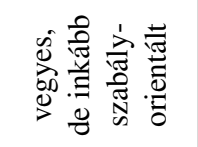 & 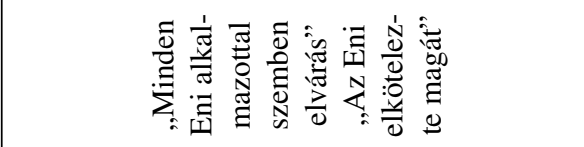 \\
\hline 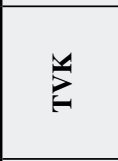 & $\therefore$ & 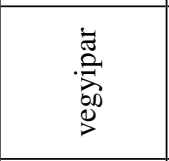 & 芯 & \begin{tabular}{l|}
$\pi$ \\
$\frac{\pi}{0}$ \\
2 \\
\end{tabular} & 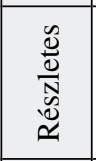 & 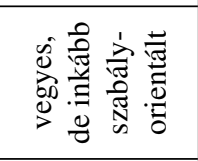 & 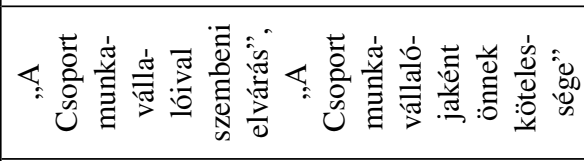 \\
\hline 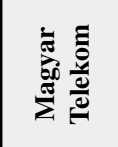 & $\stackrel{\circ}{\circ}$ & 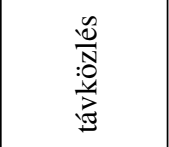 & 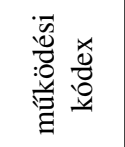 & $\begin{array}{l}\frac{\pi}{0} \\
\frac{0}{0} \\
9\end{array}$ & 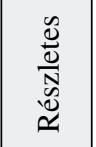 & 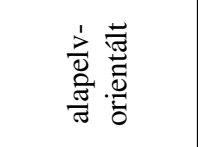 & 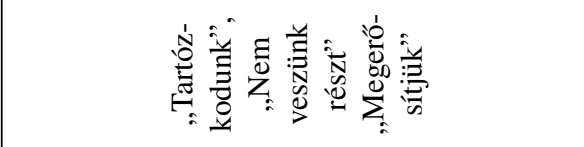 \\
\hline Z & $\therefore$ & 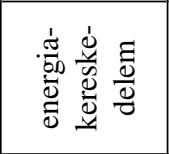 & 尝希 & \begin{tabular}{l|}
\multicolumn{3}{c}{} \\
$\frac{\pi}{0}$ \\
$\infty$ \\
$\infty$ \\
\end{tabular} & 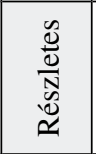 & 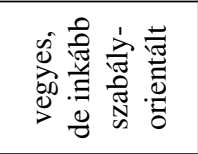 & 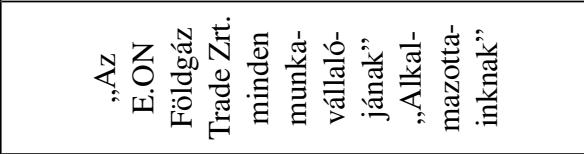 \\
\hline 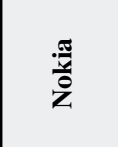 & $\dot{r}$ & 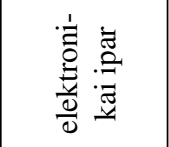 & 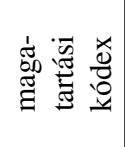 & $\begin{array}{l}\frac{\pi}{0} \\
\frac{\pi}{0} \\
\infty\end{array}$ & 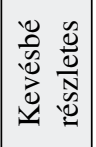 & 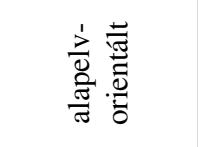 & 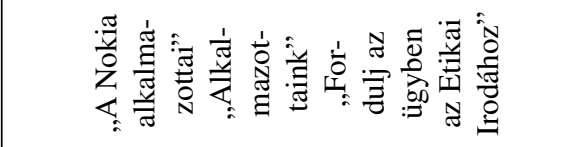 \\
\hline$\stackrel{\overrightarrow{0}}{\Sigma}$ & $\dot{-}$ & 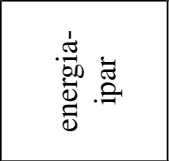 & 苛 & \begin{tabular}{l|} 
\\
$\bar{\pi}$ \\
0 \\
0 \\
\end{tabular} & 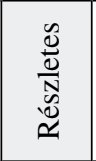 & 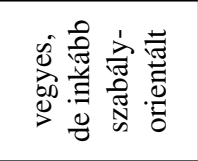 & 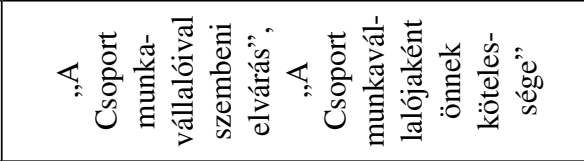 \\
\hline 吾 & 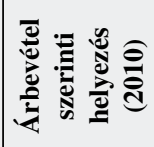 & 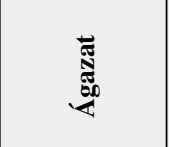 & 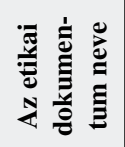 & 离 & 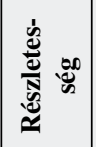 & 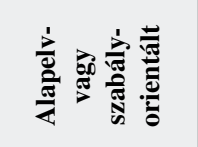 & 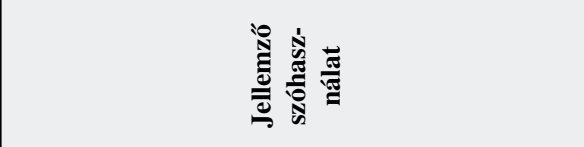 \\
\hline
\end{tabular}


vállalat alkalmazottairól. Két vizsgált kódexben jelenik meg a tegező forma, ott is csak a kérdezésre való felszólításnál: „Nem vagy egyedül. Ha nehézséget okoz a döntés, vagy ha egyszerüen aggódsz valamely kérdés miatt, konzultálj a fönököddel vagy a személyügyi vezetôvel” (Nokia, 2011: p. 7.). „Kétség esetén kérdezz!” (Metro, 2012: p. 3.) (1. táblázat).

A vizsgált vállalati körben az etikai kódexek létrehozásának céljai között a legfontosabb az, hogy a munkavállalók számára iránymutatásul szolgáljon, segítséget nyújtson a mindennapi viselkedés során. Ezt a célt a vállalatok 93\%-a hangsúlyozta, kivételt jelent a Mol Energiakereskedő Zrt., amely nem tért ki a kódex céljára. A vállalatok $86 \%$-ánál jelent meg a kódexben a vállalati felelôsség hagyományos vállalatfelfogáson túlmutató felvállalása. A vizsgált vállalatok közül csak a Richter és a Telenor nem hangsúlyozta ezt a kódexé- ben. A vállalatok $64 \%$-a szerint a vállalati felelősségvállalás és etikus viselkedés a hosszú távú gazdasági siker és versenyelôny feltétele (MOL, TVK, Nokia, EON Földgáz Trade, Magyar Telekom, TIGÁZ, OMV, Shell, Metro). A vállalatok 64\%-a célként jelölte meg a vállalati kultúra fejlesztését, $57 \%$-uk pedig a vállalati hírnév védelmét. Mintegy 30\%-nál jelent meg a bizalom erôsítése célként.

A felelősségen túl, a vizsgált kódexek mindegyikében megjelenik etikai értékként a tisztesség és a tisztelet. További értékként megtalálható az együttmúködés $(93 \%)$, a nyitottság (79\%), az átláthatóság (71\%), a becsületesség (64\%), a bizalom (64\%), a korrektség (57\%), a méltányosság (57\%).

A vizsgált kódexek témáinak áttekintéséhez LeFebvre (2011) csoportosítását alkalmaztam, ami három nagy témakört jelent, a vállalat védelme, a társadalmi

A vizsgált etikai kódexek fớ témakörei
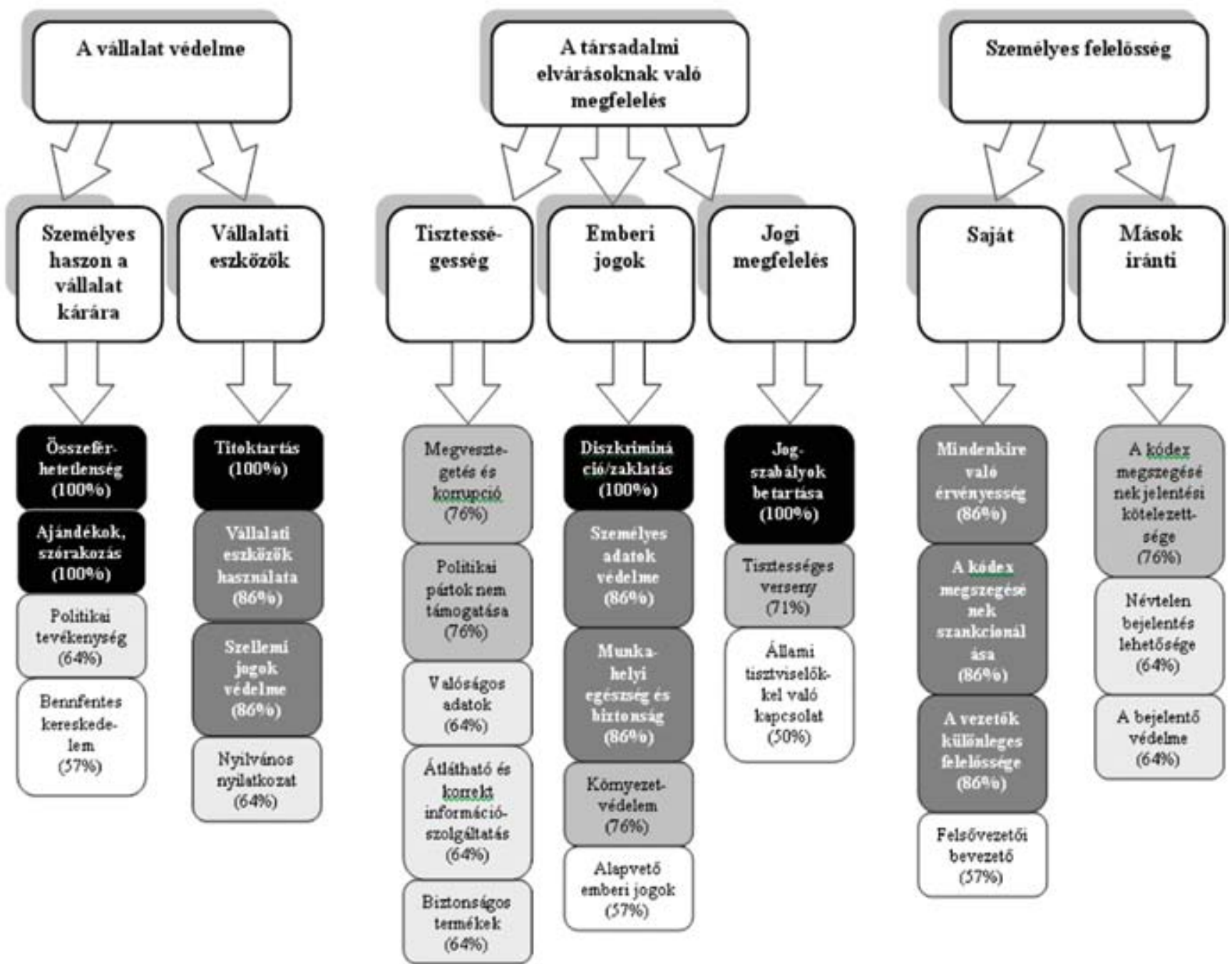

Forrás: saját szerkesztés, LeFebvre (2011: p. 13.) alapján 
elvárásoknak való megfelelés és a személyes felelősség témakörét. A vállalat védelme témakörön belül jelenik meg a személyes haszon a vállalat kárára, valamint a vállalati eszközök csoportja. A társadalmi elvárásoknak való megfelelésen belül beszélhetünk a tisztességesség, az emberi jogok, valamint a jogi megfelelés részterületrôl. A személyes felelôsségen belül pedig a saját és a mások iránti felelősségról. A LeFebvre (2011) által alkalmazott konkrét témákat kiegészítettem a vizsgált etikai kódexekben megjelenó sajátos témákkal. Az 1. ábra tartalmazza azokat a fó témákat, amelyek megjelentek a vizsgált kódexekben. Az egyes témákhoz írt százalékok az előfordulásuk gyakoriságát mutatják. A gyakoriságok alapján minél gyakrabban szerepelt egy-egy téma, annál sötétebb árnyalattal van jelölve az ábrán.

Az elemzés alapján a vizsgált vállalati etikai kódexek leggyakoribb témái az összeférhetetlenség (100\%), az ajándékok, a szórakozás (100\%), a diszkrimináció/zaklatás (100\%), valamint a jogszabályok betartása (100\%). A kódexek többségében találkozhatunk a vállalati eszközök használata (86\%), a szellemi jogok védelme (86\%), a személyes adatok védelme (86\%), a munkahelyi egészség és biztonság (86\%), a kódex mindenkire való érvényessége (86\%), a kódex megszegésének szankcionálása $(86 \%)$ és a vezetôk különleges felelôssége (86\%) témákkal. Gyakori témák a megvesztegetés és korrupció (76\%), a politikai pártok nem támogatása (76\%), a környezetvédelem (76\%), a tisztességes verseny (71\%), valamint a kódex megszegésének jelentési kötelezettsége (76\%). A kódexek mintegy kétharmadában jelenik meg a munkavállalói politikai tevékenység szabályozása (64\%), a nyilvános nyilatkozat (64\%), a valósághú adatok (64\%), az átlátható és korrekt információszolgáltatás (64\%), a biztonságos termékek és szolgáltatások (64\%), a névtelen bejelentés lehetôsége (64\%) és a bejelentô védelme (64\%). A vizsgált kódexek több mint fele tartalmazza a bennfentes kereskedelem (57\%), az alapvetô emberi jogok (57\%), az állami tisztviselókkel való kapcsolat (50\%) témaköröket, valamint elmondható, hogy a kódexek 57 százalékában van felsôvezetôi bevezetô.

A már említett LeFebvre-tanulmány (2011) empirikus része az USA és India 50 legnagyobb árbevételú vállalatának etikai kódexét vetette össze. Ezek mindegyike az interneten elérhetô volt. A magyar, az amerikai és az indiai eredményeket összevetve megállapítható, hogy két témakör, az összeférhetetlenség és a titoktartás minden egyes vizsgált vállalatnál megjelent, mindhárom országban (2. táblázat). Hat témakörben elóztük meg az amerikai vállalatokat, ezek az ajándékok és szórakozás (különbség: +4\%), nyilvános nyilatkozat $(+6 \%)$, diszkrimináció/zaklatás $(+12 \%)$, munkahelyi egészség és biztonság $(+12 \%)$, környezetvédelem $(+6 \%)$, a jogszabályok betartása $(+2 \%)$. Két témakörben elóztek meg minket az indiai vállalatok, ezek a bennfentes kereskedelem $(-19 \%)$ és a vállalati eszközök használata (-8\%). A magyar mintában kevesebb tôzsdei cég szerepelt, amiknél hangsúlyosabb a bennfentes kereskedelem témakör. A magyar vállalati kódexekben viszont 15 téma fordult elő gyakrabban, mint az indiai kódexekben. A mindenkire való érvényességnél és a jelentési kötelezettségnél 54\%, az anonim bejelentés lehetôségénél pedig $58 \%$ a különbség a javunkra. Az amerikai vállalatoknál 11 témakör jelent meg gyakrabban a vizsgált kódexekben, mint a magyar kódexekben, ráadásul viszonylag jelentôs különbséggel. Ezek a témák a politikai tevékenység (különség: $-28 \%)$, bennfentes kereskedelem $(-41 \%)$, vállalati eszközök használata $(-10 \%)$, valóságnak megfelelő adatok (-30\%), átláthatóság és korrekt információszolgáltatás $(-26 \%)$, tisztességes verseny $(-23 \%)$, mindenkire való érvényesség $(-14 \%)$, a kódex megszegésének szankcionálása $(-4 \%)$, jelentési kötelezettség $(-18 \%)$, anonim bejelentés lehetôsége (-24\%), a bejelentô védelme (-34\%) (2. táblázat).

\section{Összefoglalás}

A vizsgálat rámutatott arra, hogy a magyar vállalati kódexek a fó témaköröket tekintve 74\%-ban megegyeznek egymással. Kiemelt szerepet kap az összeférhetetlenség, az ajándékok és szórakozás, a diszkrimináció/ zaklatás, valamint a jogszabályok betartása. A vizsgált magyar és amerikai kódexek átlagosan 16\%-ban térnek el egymástól. Az etikai kódexek által szabályozott témák vonatkozásában jelentôs lemaradás mutatkozik a magyar vállalatok körében a bennfentes kereskedelem, a valósághú adatok és átlátható információszolgáltatás, a tisztességes verseny, az anonim bejelentés lehetősége, valamint a bejelentốk védelme területén.

Ugyancsak elgondolkodtató, hogy míg a TOP 50 amerikai és indiai vállalat $100 \%$-a nyilvánosan elérhetóvé teszi az etikai kódexét, ez a magyar TOP 50 esetén mindössze $28 \%$. Az összehasonlító adatok a magyar vállalati kódexek fejletlenségére engednek következtetni az amerikai gyakorlathoz képest. A hazai kódexekben célszerú a saját és a mások iránti felelősség erősítése. A kódexekben megjelenó határozott felsôvezetôii elkötelezettség, a mindenkire érvényes bejelentési kötelezettség, a névtelen bejelentési lehetőség és a bejelentốk védelmének hangsúlyozása elôsegítené a kódexben foglaltak vállalati kultúrába integrálását. 
Az etikai kódexek témáinak összehasonlítása

\begin{tabular}{|c|c|c|c|c|c|}
\hline Téma & $\begin{array}{c}\text { Magyar válla- } \\
\text { latok körében } \\
\text { az eloofordulás } \\
\text { gyakorisága } \\
(\%)\end{array}$ & $\begin{array}{c}\text { Amerikai } \\
\text { vállalatok } \\
\text { körében az } \\
\text { előfordulás } \\
\text { gyakorisága } \\
(\%)\end{array}$ & $\begin{array}{c}\text { Eltérés a } \\
\text { magyar és az } \\
\text { amerikai ada- } \\
\text { tok között } \\
(\%)\end{array}$ & $\begin{array}{c}\text { Indiai válla- } \\
\text { latok körében } \\
\text { az eloofordulás } \\
\text { gyakorisága } \\
(\%)\end{array}$ & $\begin{array}{c}\text { Eltérés a } \\
\text { magyar és az } \\
\text { indiai adatok } \\
\text { közöttt } \\
(\%)\end{array}$ \\
\hline \multicolumn{6}{|l|}{ A vállalat védelme } \\
\hline \multicolumn{6}{|l|}{ Személyes haszon a vállalat kárára } \\
\hline Összeférhetetlenség & 100 & 100 & 0 & 100 & 0 \\
\hline Ajándékok, szórakozás & 100 & 96 & 4 & 92 & 8 \\
\hline Politikai tevékenység & 64 & 82 & -28 & 26 & 28 \\
\hline Bennfentes kereskedelem & 57 & 98 & -41 & 76 & -19 \\
\hline \multicolumn{6}{|l|}{ Vállalati eszközök } \\
\hline Titoktartás & 100 & 100 & 0 & 100 & 0 \\
\hline Vállalati eszközök használata & 86 & 96 & -10 & 94 & -8 \\
\hline Szellemi jogok védelme & 86 & n. a. & n. a. & n. a. & n. a. \\
\hline Nyilvános nyilatkozat & 64 & 58 & 6 & 56 & 8 \\
\hline \multicolumn{6}{|l|}{ A társadalmi elvárásoknak való megfelelés } \\
\hline \multicolumn{6}{|l|}{ Tisztességesség } \\
\hline Megvesztegetés és korrupció & 76 & n. a. & n. a. & n. a. & n. a. \\
\hline Politikai pártok nem támogatása & 76 & n. a. & n. a. & n. a. & n. a. \\
\hline Valóságnak megfelelő adatok & 64 & 94 & -30 & 32 & 32 \\
\hline Átláthatóság és korrekt információszolgáltatás & 64 & 90 & -26 & 62 & 2 \\
\hline Biztonságos termékek & 64 & n. a. & n. a. & n. a. & n. a. \\
\hline \multicolumn{6}{|l|}{ Emberi jogok } \\
\hline Diszkrimináció/zaklatás & 100 & 88 & 12 & 44 & 56 \\
\hline Személyes adatok védelme & 86 & n. a. & n. a. & n. a. & n. a. \\
\hline Munkahelyi egészség és biztonság & 86 & 74 & 12 & 66 & 20 \\
\hline Környezetvédelem & 76 & 70 & 6 & 46 & 30 \\
\hline Alapvetô emberi jogok & 57 & n. a. & n. a. & n. a. & n. a. \\
\hline \multicolumn{6}{|l|}{ Jogi megfelelés } \\
\hline Jogszabályok betartása & 100 & 98 & 2 & 96 & 4 \\
\hline Tisztességes verseny & 71 & 94 & -23 & 32 & 39 \\
\hline Állami tiszviselőkkel való kapcsolat & 50 & n. a. & n. a. & n. a. & n. a. \\
\hline \multicolumn{6}{|l|}{ Személyes felelôsség } \\
\hline \multicolumn{6}{|l|}{ Saját } \\
\hline Mindenkire való érvényesség & 86 & 100 & -14 & 32 & 54 \\
\hline A kódex megszegésének szankcionálása & 86 & 90 & -4 & 68 & 18 \\
\hline A vezetők különleges felelőssége & 86 & n. a. & n. a. & n. a. & n. a. \\
\hline Felsővezetôi bevezető & 57 & n. a. & n. a. & n. a. & n. a. \\
\hline \multicolumn{6}{|l|}{ Mások iránti } \\
\hline A kódex megszegésének jelentési kötelezettsége & 76 & 94 & -18 & 22 & 54 \\
\hline Névtelen bejelentés lehetôsége & 64 & 88 & -24 & 6 & 58 \\
\hline A bejelentő védelme & 64 & 98 & -34 & 34 & 30 \\
\hline
\end{tabular}

Forrás: A magyar adatok jelen kutatásból származnak, az amerikai és indiai adatok forrása LeFebvre (2011) 


\section{Lábjegyzet}

${ }^{1}$ A bemutatott kutatómunka a TÁMOP-4.2.1.B-10/2/KONV-20100001 jelú projekt részeként az Európai Unió támogatásával, az Európai Szociális Alap társfinanszírozásával valósul meg.

\section{Felhasznált irodalom}

Becker, H. - Frietzsche, D.J. (1987): Business Ethics: A Cross-Cultural Comparison of Managers Attitudes. Journal of Business Ethics, 6.

Bondy, K. - Matten, D. - Moon, J. (2004): The Adoption of Voluntary Codes of Conduct in MNCs: A Three-Country Comparative Study, Business and Society Review, 109 (4), p. 449-477.

Borsod Chem Csoport (2008): A BorsodChem Csoport Etikai kódexe. http://www.borsodchem-hu.com/ getmedia/06554cd6-8cec-410d-9282-2cc7620dcadf/ BC_etikai_kodex_magyar_web.aspx Letöltve: 2012. május 28.

Bowie, N. (1990): Business Codes of Ethics: WindowDressing or Legitimate Alternative to Government Regulation? in: W. Hoffman and J. Moore (eds.): Business Ethics: Readings and cases in corporate morality. New York: McGraw-Hill, p. 505-509.

Clark, M. (1980): Corporate Codes of Ethics: A Key to Economic Freedom, Management Review, 69, p. 60-62.

Cleek, M.A. - Leonard, S.L. (1998): Can Corporate Codes Ethics Influence Behavior? Journal of Business Ethics, 17(6), p. 619-630.

Cooper, N. (1990): Foreword in Developing a Code of Business Ethics. London: Institute of Business Ethics

Coughlan, R. (2005): Codes, Values and Justifications in the Ethical Decision-Making Process. Journal of Business Ethics, 59, p. 45-53.

Cowton, C. - Thomspon, P. (2000): Do Codes Make a Difference? The Case of Bank Lending and the Environment. Journal of Business Ethics, 24, p. 165-178.

Cressey, D. - Moore, C. (1983): Managerial Values and Corporate Codes of Ethics. California Management Review, 25, p. 53-77.

Dobel, J. (1993): The Realpolitik of Ethics Codes: An Implementation Approach to Public Ethics. in: $\mathrm{H}$. Frederickson (eds.): Ethics and Public Administration. New York: Sharpe, p. 158-171.

Dobson, J. (2005): Monkey Business: A Neo-Darwinist Approach to Ethics Codes, Financial Analysts Journal, 61, p. 59-64.

E.ON Földgáz Trade Zrt. (2012): Az E.ON Földgáz Trade Zrt. Etikai Kódexe. http://www.eon-foldgaz-trade.com/ felelossegvallalas/erikai-kodex Letöltve: 2012. május 28.

Epstein, E.M. (2006): The "good company," rhetoric or reality? Corporate social responsibility and business ethics redux. http://www.stthomas.edu/cathstudies/cst/ conferences/thegoodcompany/Finalpapers/Epstein,\%20 The\%20Good\%20Co.pdf Letöltés: 2011. október 25.
Hassink, H. - de Vries, M. - Bollen, L. (2007): A Content Analysis of Whistleblowing Policies of Leading European Companies. Journal of Business Ethics, 75, p. 25-44.

Hess, D. - McWhorter, R. - Fort, T. (2006): The 2004 Amendments to the Federal Sentencing Guidelines and Their Implicit Call for a Symbiotic Integration of Business Ethics. Fordham Journal of Corporate \& Financial Law, 11, p. 725-764.

HVG (2011): Az 500 legnagyobb árbevételú hazai cég. HVG 2011. október 8., 54. o.

Kaptein, M. - Schwartz, M. (2008): The Effectiveness of Business Codes: A Critical Examination of Existing Studies and the Development of an Integrated Research Model. Journal of Business Ethics, 77, p. 111- 127.

Kaptein, M. - Wempe, J. (1998): Twelve Gordian Knots when Developing a Code of Conduct. Journal of Business Ethics, 17, p. 853-869.

KPMG (2008): Business Code of the Global 200: Their Prevalence, Content and Embedding (KPMG, Amsterdam). 2011. január 15-i megtekintés. http://www.kpmg.com/CN/en/Issues AndInsights/ ArticlesPublications/Documents/business_codes_ global_200_O_0804.pdf

L'Etang, J. (1992): A Kantian Approach to Codes of Ethics. Journal of Business Ethics, 11, p. 737-744.

LeFebvre, R. (2011): Cross-Cultural Comparison of Business Ethics in the U.S. and India: A Study of Business Codes of Conduct. Journal of Emerging Knowledge on Emerging Markets, Volume 3. November

Logsdon, J. - Wood, D. (2005): Global Business Citizenship and Voluntary Codes of Ethical Conduct. Journal of Business Ethics, 59, p. 55-67.

LRN (2010): Ethics \& Compliance Leadership SURVEY REPORT 2010-2011

Magyar Telekom Nyrt. (2011): Múködési Kódex. http:// www.telekom.hu/static/sw/download/MT_Mukodesi_ Kodex_20110331.pdf Letöltve: 2012. május 28.

Manley, W. (1991): Executive's Handbook of Model Business Conduct Codes. New York: Prentice-Hall

Matthews, M.C. (1990): Codes of Ethics: Organization Behavior and Misbehavior. in: Frederick, W.C. Preston, L. E. (1990): Business Ethics: Research Issues and Empirical Studies. Greenwich, CT: JAI Press Inc.

McClintock, B. (1999): The Multinational Corporation and Social Justice: Experiments in Supranational Governance. Review of Social Economy, 57, p. 502-522.

Metro (2012): A METRO Cash \& Carry dolgozóira vonatkozó Üzleti Alapelvek. http://www.metro.hu/ download/002/432/metro_viselkedes_v4.pdf Letöltve: 2012. május 28.

Mezher, T. - Jamali, D. - Zreik, C. (2002): The Role of Financial Institutions in the Sustainable Development of Lebanon. Sustainable Development, 10, p. 69-78.

Mol Energiakereskedó Zrt. (2012): Etikai kódex. http:// www.molenergiakereskedo.hu/hu/etikai-kodex Letöltve: 2012. május 28. 
Mol Group (2012): Etikai kódex. www.mol.hu. Letöltve: 2012. május 28.

Murphy, P. (1988): Implementing Business Ethics. Journal of Business Ethics, 7, p. 907-915.

Newton, L.H. (1995): The Many Faces of Corporate Code. in: Hoffman-Frederick: Business Ethics. New York: McGraw-Hill

Nokia (2011) Nokia magatartási kódex. http://ncomprod. nokia.com/NOKIA_COM_1/Corporate_Responsibility/ Ethics/Tools/Code_of_conduct/pdf/code_hungary_ brochure_www.pdf Letöltve: 2012. május 28.

Norberg, P. (2009): “I don't Care that People don't Like What I Do" - Business Codes Viewed as Invisible or Visible Restrictions. Journal of Business Ethics, 86, p. 211-225.

O'Dwyer, B. - Madden, G. (2006): Ethical Codes of Conduct in Irish Companies: A Survey of Code Content and Enforcement Procedures. Journal of Business Ethics, 63 (3), p. 217-236.

OMV (2009): Etikai kódex. http://www.omv.hu/ SecurityServlet/secure?cid=1239966914889\&lang=hu \&swa_id=54158383392.72947\&swa_site=wps.vp.hu Letöltve: 2012. május 28.

Pitt, H. - Groskaufmanis, K. (1990): Minimizing Corporate Civil and Criminal Liability: A Second Look at Corporate Codes of Conduct. Georgetown Law Journal, 78, p. 1559-1654.

Raiborn, C. - Payne, D. (1990): Corporate Codes of Conduct: A Collective Conscience and Continuum. Journal of Business Ethics, 9, p. 879-989.

Rezaee, Z. - Elmore, R. - Szendi, J (2001): Ethical Behavior in Higher Educational Institutions: The Role of the Code of Conduct. Journal of Business Ethics, 30, p. 171-183.

Richter Gedeon Vegyészeti Gyár Nyrt. (2009): Etikai kódex. http://www.richter.hu/HU/Pages/etikaikod.aspx Letöltve: 2012. május 28.

Ross, D.L. - Benson, J.A. (1995): Cultural Change in Ethical Redemption: A Corporate Case Study. Journal of Business Communication, 32 (4), p. 345-362.

Schwartz, M. (2000): Why Ethical Codes Constitute an Unconscionable Regression. Journal of Business Ethics, 19 (2), p. 173-184.

Schwartz, M. (2001): The Nature of the Relationship Between Corporate Codes of Ethics and Behavior. Journal of Business Ethics, 32, p. 247-262.

Sethi, P. (2002): Standards for Corporate Conduct in the International Arena: Challenges and Opportunities for Multinational Corporations. Business and Society Review, 107, p. 20-40.

Shell (2006): Etikai kódex. http://www.shell.com/static/ hun/downloads/aboutshell/shell_etikai_kodex_hu.pdf Letöltve: 2012. május 28.

Singhapakdi, A. - Vitell, S.J. (1990): Marketing Ethics: Factors Influencing Perceptions of Ethical Problems and Alternatives. Journal of Macro Marketing, 12 (Spring)

Stevens, B. (2008): Corporate Ethical Codes: Effective Instruments For Influencing Behavior. Journal of Business Ethics, 78, p. 601-609.

Szegedi K. (2011): A vállalati etikai kódexek szerepe a gyakorlatban - a MOL-csoport példája. in: Borgulya Á. - Deák Cs. (Szerk.) (2011): Vállalati kommunikáció a 21. század elején. Miskolc: Z-Press

Szerencsejáték Zrt. (2010): Etikai kódex. http://www. szerencsejatek.hu/etikai-kodex Letöltve: 2012. május 28.

Telenor (2010): Etikai kódex. http://www.telenor.hu/upload/ pr/Telenor_EtikaiKodex_2010majus.pdf Letöltve: 2012. május 28.

TIGÁZ Tiszántúli Gázszolgáltató Zrt. (2008): Etikai kódex, ENI. https://www.tigaz.hu/dokumentumok/Eni\%20 etikai\%20k\%C3\%B3dex.pdf Letöltve: 2012. május 28.

Trevino, L.K. (1986): Ethical Decision Making in Organizations: A Person-Situation Interactionist Model. Academy of Management Review, 11(3), p. 601-617.

Ulrich, P. - Lunau, Y. - Weber, T. (1996): Ethikmassnahmen in der Praxis, Berichte und Beiträge Nr. 73, St. Gallen: Institut für Wirtschaftsethik

Warner, F. (2001): Going Once, Going Twice... 2010. november 10-i megtekintés. http://www.fastcompany. com/articles/2002/03/ebay.html

Warren, R. (1993): Codes of Ethics: Bricks Without Straw. Business Ethics: A European Review, 2, p. 185-191.

Weaver, G.R. - Trevino, L.K. - Cochran, P.L. (1999): Integrated and Decoupled Corporate Social Performance: Management Values, External Pressures, and Corporate Ethics Practices. Academy of Management Journal, 42, p. 539-552.

White, B. - Montgomery, B. (1980): Corporate Codes of Conduct. California Management Review, 23, p. 80-87.

Wood, G. (2000): A Cross Cultural Comparison of the Contents of Codes of Ethics: USA, Canada, and Australia. Journal of Business Ethics, 25, p. 287-298.

Wood, G. - Rimmer, M. (2003): Codes of Ethics: What Are They Really and What Should They Be? International Journal of Value-Based Management, 16, p. 181-195. 